\title{
Large oesophageal haematoma as a result of transoesophageal echocardiogram (TEE)
}

\author{
Mandeep Singh Randhawa, Manoj P Rai, Gaurav Dhar, Appa Bandi
}

Division of Cardiology, Department of Internal Medicine, Michigan State University / Sparrow Hospital East Lansing, Michigan, USA

\section{Correspondence to \\ Dr Manoj P Rai}

manoj.rai@hc.msu.edu

Accepted 25 October 2017

\section{E \\ CrossMark}

To cite: Randhawa MS, Rai MP, Dhar G, et al. BMJ Case Rep Published Online First: [please include Day Month Year]. doi:10.1136/ bcr-2017-223278

\section{DESCRIPTION}

This is a 68-year-old man with known type A aortic dissection, post ascending aorta repair and mechanical aortic valve who presented with symptomatic severe mitral regurgitation secondary to a degenerative valve. Due to prohibitive surgical risk, the patient underwent transcatheter mitral clip placement under the guidance of transoesophageal echocardiogram (TEE). Post procedure the patient developed haematemesis and dysphagia to solid food. The patient underwent fluoroscopy, which showed oesophageal stricture (figure 1). The next morning labs showed a significant drop in

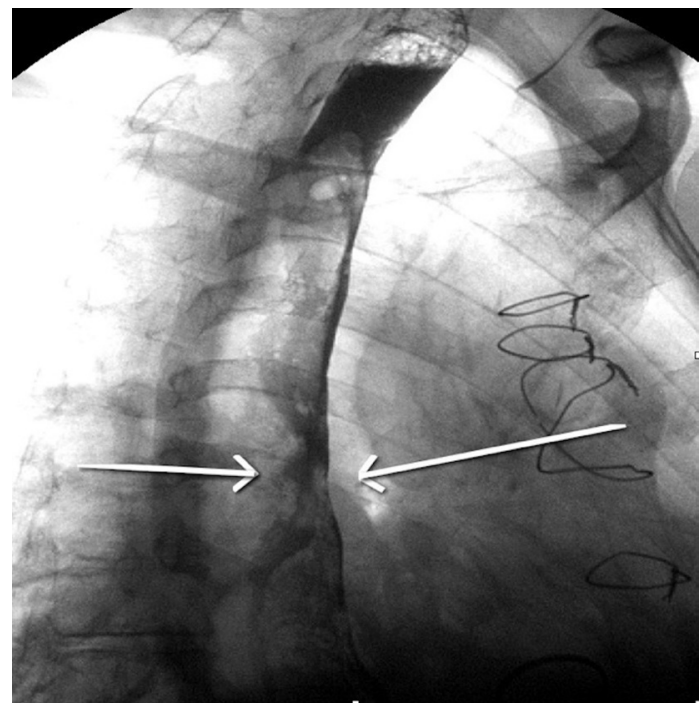

Figure 1 Fluoroscopy showing oesophageal stricture.

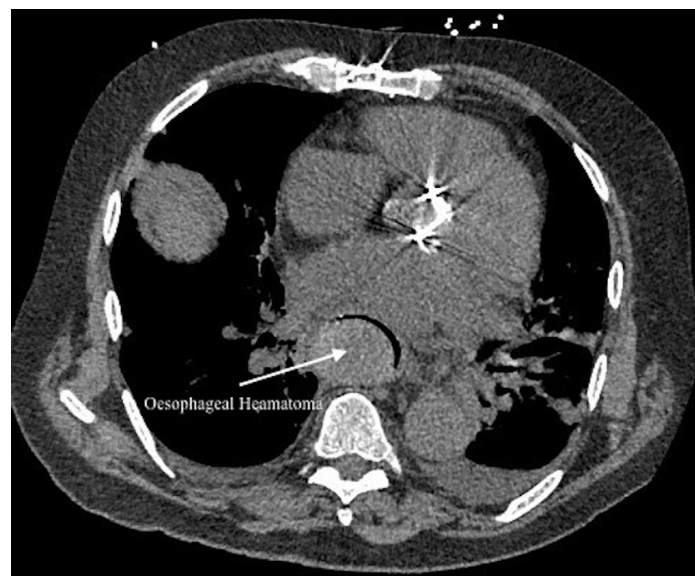

Figure 2 CT scan (axial section) showing large submucosal oesophageal $22 \mathrm{~cm} \times 3.2 \mathrm{~cm} \times 3.8 \mathrm{~cm}$ haematoma.

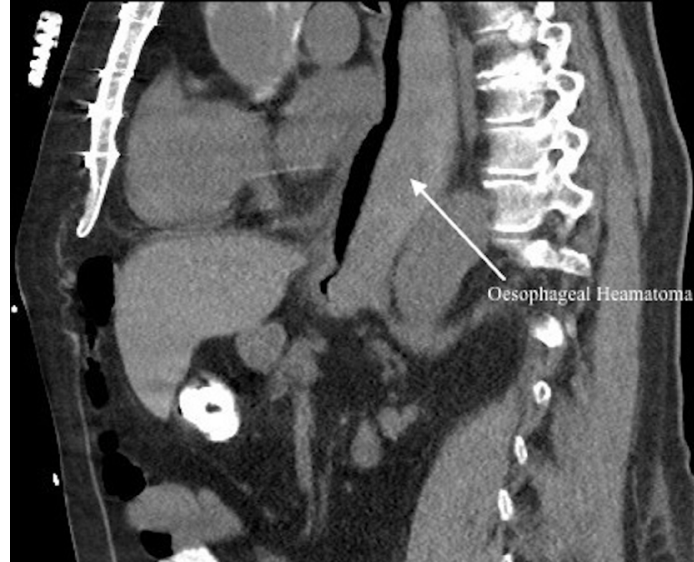

Figure 3 CT scan (coronal section) showing large submucosal oesophageal $22 \mathrm{~cm} \times 3.2 \mathrm{~cm} \times 3.8 \mathrm{~cm}$ haematoma.

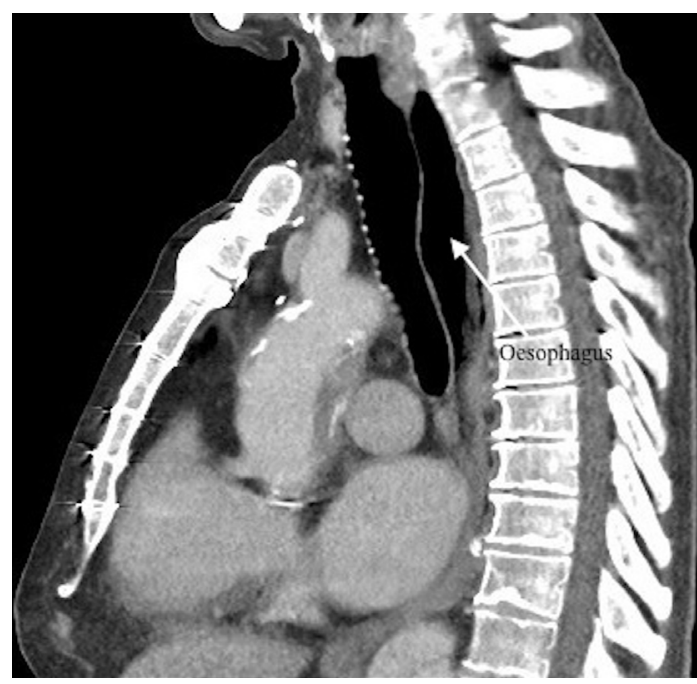

Figure 4 Interval CT scan of the chest 4 months after the procedure showing significant resolution of the haematoma.

haemoglobin to $6.9 \mathrm{~g} / \mathrm{dL}$ requiring 1 unit of packed red blood cells. Contrast-enhanced CT scan of chest and abdomen was then performed, which showed large submucosal oesophageal $22 \mathrm{~cm} \times 3.2 \mathrm{~cm} \times$ $3.8 \mathrm{~cm}$ haematoma (figures 2 and 3 ). Haematoma extended along the entire length of the oesophagus and was severely compromising the oesophageal lumen (figure 3). On admission the patient was on warfarin for mechanical aortic valve, which was held before the procedure and was resumed afterwards. The patient was managed conservatively with mechanical soft diet. An interval CT scan 


\section{Learning points}

- Even though oesophageal haematoma is rare (as low as $3 / 1100)$, it is a possible complication of transoesophageal echocardiogram.

- Oesophageal haematomas generally resolve with conservative management.

of the chest 4 months after the procedure showed significant resolution of the haematoma (figure 4). There was a gradual improvement of dysphagia. An oesophageal haematoma is a rare phenomenon especially in a patient who is off anticoagulation. It usually presents with dysphagia or haematemesis. ${ }^{1}$ According to a single-centre study, its incidence is as low as 3/1100 in patients undergoing TEE. ${ }^{2}$ Oesophageal haematoma generally resolves with no long-term sequelae with conservative management only.
Contributors MSR worked on the manuscript (case and the description). MPR assisted with writing the manuscript and obtained patient consent. GD and AB were involved in the patient care, and they revised the manuscript and provided the images.

Competing interests None declared.

Patient consent Obtained.

Provenance and peer review Not commissioned; externally peer reviewed.

(c) BMJ Publishing Group Ltd (unless otherwise stated in the text of the article) 2017. All rights reserved. No commercial use is permitted unless otherwise expressly granted.

\section{REFERENCES}

1 Ackert JJ, Sherman A, Lustbader IJ, et al. Spontaneous intramural hematoma of the esophagus. Am J Gastroenterol 1989;84:1325-8.

2 Kumar S, Ling LH, Halloran K, et al. Esophageal hematoma after atrial fibrillation ablation: incidence, clinical features, and sequelae of esophageal injury of a different sort. Circ Arrhythm Electrophysiol 2012;5:701-5.

Copyright 2017 BMJ Publishing Group. All rights reserved. For permission to reuse any of this content visit http://group.bmj.com/group/rights-licensing/permissions.

BMJ Case Report Fellows may re-use this article for personal use and teaching without any further permission.

Become a Fellow of BMJ Case Reports today and you can:

- Submit as many cases as you like

- Enjoy fast sympathetic peer review and rapid publication of accepted articles

- Access all the published articles

- Re-use any of the published material for personal use and teaching without further permission

For information on Institutional Fellowships contact consortiasales@bmjgroup.com

Visit casereports.bmj.com for more articles like this and to become a Fellow 